Original Article

\title{
DETECTION OF ENTEROPATHOGENIC ESCHERICHIA COLI (EPEC) BY SEROTYPING AND CELL ADHESION ASSAY AMONG CHILDREN IN NORTH-EASTERN PENINSULAR MALAYSIA-A HOSPITAL BASED STUDY
}

\author{
J Ashraful Haq ${ }^{1}$, Hin Choon $\mathrm{Li}^{2}$ and Rosliza Abdur Rahman² \\ ${ }^{I}$ Department of Microbiology, Bangladesh Institute of Research and Rehabilitation for Diabetes, \\ Endocrine and Metabolic Disorders (BIRDEM), Dhaka, ${ }^{2}$ Department of Microbiology \& \\ Parasitology, University Sains Malaysia, Kubang Kerian 16150, Kelantan, Malaysia
}

\begin{abstract}
Enteropathogenic Escherichia coli (EPEC) is a major cause of diarrhea in children below 5 years of age in the developing countries. The present study investigated the role of EPEC in childhood diarrhea among the patients attending a university hospital in north-eastern peninsular Malaysia by serotyping and cell adhesion assay using HEp- 2 and HeLa cells. A total of 60 stools or rectal swabs from watery diarrhea cases and 16 age matched healthy controls were examined. EPEC were isolated from $14(23.3 \%)$ diarrhea cases and from 1 (9.1\%) control by serotyping. Of the 14 EPEC strains, the predominant strain was 0125: K70 (28.5\%). Cell adhesion assay detected $26.6 \%$ and $30.0 \%$ adherent Escherichia coli (E. coli) in diarrhea cases by HEp-2 and HeLa system respectively. Three adherence patterns were noted namely localized, diffuse and aggregative patterns. About 81$88 \%$ of isolated E. coli exhibited diffuse adherence pattern by HEp-2 and HeLa cell assay respectively. About $43-44 \%$ E. coli exhibiting positive cell adherence phenotype with HEp-2 and HeLa cell assays tested negative with EPEC antisera. The findings indicate that EPEC is an important cause of childhood diarrhea in north-eastern peninsular Malaysia and cell adhesion assay is more sensitive than serotyping for detection of diarrheogenic $E$. coli.
\end{abstract}

Ibrahim Med. Coll. J. 2008; 2(2): 40-43

Key Words: EPEC, diarrhea, serotyping, Malaysia

\section{Introduction}

Enteropathogenic Escherichia coli (EPEC) is a leading cause of acute diarrhea among children in developing countries. It accounts for about $7-23 \%$ of all diarrhea pathogens. ${ }^{1-4}$ EPEC attaches to the brush border of the mucous membrane of the small intestine in a characteristic manner, producing ultra structural changes known as attachment effacement (AE) lesions. ${ }^{5}$ The AE lesion is mediated by intimate attachment of bacteria to the apical enterocyte causing localized destruction of brush border microvilli and perhaps thereby mediating increased secretion. ${ }^{3}$ The laboratory counterpart of muscosal colonization is adherence of EPEC to cells such as HEp-2 and HeLa cells. E. coli exhibiting localized adherence (LA), diffuse adherence
(DA), aggregative adherence (AA) and localized adherence-like (LAL) patterns with HEp-2 or HeLa cells has been implicated as diarrhreal pathogens. ${ }^{6,7}$ Among the three phenotypes, LA is highly correlated with classic EPEC serotypes. However, studies have demonstrated that $E$. coli exhibiting DA pattern should be considered enteropathogenic as $38.2 \%$ of isolated E. coli from diarrhea cases exhibited DA in HEp-2 cell compared to $8-9 \%$ of controls. ${ }^{2}$ Fluorescence actin staining (FAS) test was reported for the identification of $E$. coli causing the AE lesion. ${ }^{8}$ Recently, it has been shown that cortactin is necessary for organizing actin pedestals in response to EPEC in HeLa cells. ${ }^{9}$

Address for Correspondence:

Dr. J Ashraful Haq, Professor of Microbiology, Ibrahim Medical College \& Bangladesh Institute of Research and Rehabilitation for Diabetes, Endocrine and Metabolic Disorders (BIRDEM), Shahbagh, Dhaka-1000, e-mail: jahaq54@yahoo.com 
Detection of EPEC $\mathbf{4 1}$

To date, no information is available on the prevalence of EPEC and its different phenotypes in childhood diarrhea among the children of north-eastern peninsular Malaysia. In view of the above, this study was undertaken to find out the role of diarrheogenic $E$. coli in acute diarrhea among children below 5 years of age attending Hospital University Sains Malaysia (HUSM) at Kota Bharu, Kelantan - a town located in north-eastern peninsular Malaysia.

\section{Materials and Methods}

\section{Study population}

Stools or rectal swabs were obtained from children below 5 years of age attending HUSM with acute diarrhea. HUSM is located in Kota Bharu, Kelantan, the northeastern state of Malaysia. Acute diarrhea was defined as four or more loose stools a day, with or without abdominal pain and fever for at least one day. The duration of the episode should be less than ten days. ${ }^{10}$ Age matched healthy children without history of diarrhea one month prior to the date of enrollment in the study was included as control.

\section{Microbiological methods}

All the rectal swabs or fecal samples were plated on MacConkey agar, SS agar and TCBS media and incubated over night at $37^{\circ} \mathrm{C}$. Randomly five suspected colonies of $E$. coli were picked up and sub cultured separately on MacConky agar media and identified by standard biochemical test. ${ }^{11}$ All isolated $E$. coli strains were stored separately in nutrient agar slant at $4^{\circ} \mathrm{C}$ until used for cell assay and serotyping. Attempts were made to identify other enteropathogens namely, Shigella, Salmonella, Vibrio cholerae and rotavirus.

In the present study, HEp-2 and HeLa cell lines were used for determining adherence pattern of isolated $E$. coli. Cell adhesion assay was performed as described by Nataro et al. ${ }^{5}$ Slide agglutination test was carried out with EPEC polyvalent antisera 2,3 and 4 (Murex, $\mathrm{UK}$ ) according to the manufacturer's instruction for $\mathrm{O}$ and $\mathrm{K}$ antigens. E. coli strain positive by polyvalent antisera was tested with monovalent antisera to identify the specific EPEC serotype.

\section{Result}

In this study, 60 stool samples or rectal swabs were collected from children with acute diarrhea while 16
Table-1: Rate of isolation of EPEC from diarrhea cases $(n=60)$ by serotyping

\begin{tabular}{lcc|c}
\hline $\begin{array}{l}\text { Polyvalent } \\
\text { antisera }\end{array}$ & $\begin{array}{c}\text { Total No. } \\
\text { positive (\%) }\end{array}$ & $\begin{array}{c}\text { Monovalent } \\
\text { antisera }\end{array}$ & $\begin{array}{c}\text { No. } \\
\text { positive }\end{array}$ \\
\hline Polyvalent 2 & $5(8.3)$ & $0126: \mathrm{K} 60(\mathrm{~B} 6)$ & 1 \\
& & $0111: \mathrm{K} 58(\mathrm{~B} 5)$ & 1 \\
& & O119:K69(B14) & 1 \\
Polyvalent 3 & $6(10.0)$ & O126:K71(B16) & 2 \\
& & O86:K61(B7) & 1 \\
& & O125:K70(B15) & $4(28.5 \%)^{*}$ \\
Polyvalent 4 & $3(5.0)$ & O128:K67(B12) & 1 \\
& & O124:K74(L) & 1 \\
Total & $\mathbf{1 4}(\mathbf{2 3 . 3})$ & & \\
\hline
\end{tabular}

Note: Only one EPEC was detected out of 16 control subjects $(6.25 \%)$ by EPEC antisera (Polyvalent 4 )

* Out of 14 serotype positive EPEC

samples were taken from age matched healthy children without diarrhea as control. Out of 60 diarrhea cases, $36(60 \%)$ were below 2 years of age. EPEC serotype was isolated from $14(23.3 \%)$ diarrhea cases by serotyping (Table 1). Nine different serotypes of EPEC were isolated and the most prevalent strain was 0125:K70 by serotyping (28.57\%). Only one EPEC $(6.25 \%)$ was isolated from healthy control children.

Table 2 shows the results of HeLa and HEp- 2 cell adhesion assay of $E$. coli isolated from diarrhea and control cases. Out of 60 diarrhea cases, $30.0 \%$ and $26.6 \%$ showed one or other adherence pattern with HeLa and HEp-2 cells assay respectively. The comparative figures for the control were only $12.5 \%$ and $6.25 \%$ respectively. Diffuse adherence (DA) pattern was predominant in both HeLa and HEp-2 cell

Table-2: Results of HeLa and HEp-2 cell adhesion assay of $E$. coli isolated from diarrheal and control cases

\begin{tabular}{l|c|c|c|c}
\hline Adherence & \multicolumn{2}{|c|}{ Diarrhea cases(n=60) } & \multicolumn{2}{c}{ Health Control(n=16) } \\
\cline { 2 - 5 } Pattern & $\begin{array}{c}\text { No.positive } \\
\text { in HEp-2 } \\
\text { cells (\%) }\end{array}$ & $\begin{array}{c}\text { No.positive } \\
\text { in HeLa } \\
\text { cells (\%) }\end{array}$ & $\begin{array}{c}\text { No.positive } \\
\text { in HEp-2 } \\
\text { cells (\%) }\end{array}$ & $\begin{array}{c}\text { No.positive } \\
\text { in HeLa } \\
\text { cells (\%) }\end{array}$ \\
\hline $\begin{array}{l}\text { Diffuse } \\
\text { adherence }\end{array}$ & $13(21.66)$ & $16(26.66)$ & 0 & 2 \\
$\begin{array}{l}\text { Localized } \\
\text { adherence }\end{array}$ & $1(1.66)$ & $1(1.66)$ & 0 & 0 \\
$\begin{array}{l}\text { Aggregative } \\
\text { adherence } \\
\text { Total }\end{array}$ & $2(3.33)$ & $1(1.66)$ & 1 & 0 \\
\hline
\end{tabular}


Table-3: Relationship of cell adherence assay and serotyping by EPEC antisera

\begin{tabular}{l|c|c|c}
\hline \multirow{2}{*}{$\begin{array}{c}\text { Cell ahdrence } \\
\text { assay }\end{array}$} & $\begin{array}{c}\text { Total } \\
\text { Positive }\end{array}$ & $\begin{array}{c}\text { No. Positive } \\
\text { by EPEC } \\
\text { antisera(\%) }\end{array}$ & $\begin{array}{c}\text { No. Negative } \\
\text { by EPEC } \\
\text { antisera(\%) }\end{array}$ \\
\hline HEp-2 Cells & 16 & $9(56.3)$ & $7(43.7)$ \\
HeLa Cells & 18 & $10(55.6)$ & $8(44.4)$ \\
\hline
\end{tabular}

Note: Out of 14 serotype positive EPEC strains, $35.7 \%$ and $28.6 \%$ were negative by HEp-2 and HeLa cell assays respectively.

assay systems. Out of total strains positive by cell adherence assay, $81.25 \%$ and $88.88 \%$ exhibited DA pattern by HEp-2 and HeLa cell respectively.

Table 3 shows that about $44.0 \%$ of $E$. coli that was positive in cell adherence assay was negative by EPEC antisera. The single EPEC isolated from control case did not show any adherence pattern with HeLa or HEp2 cells assay.

\section{Discussion}

Serotype positive and cell adherent $E$.coli were isolated in significantly $(\mathrm{p}<0.05)$ higher number from diarrhea cases compared to the control by serotyping and cell adhesion assays respectively. It implicated that EPEC was an important cause of diarrhea in children in Kelantan area. The predominant EPEC serotype was 0125:K70 (28.5\%). Amongst the EPEC serotypes, over 81-88\% exhibited DA pattern of adherence with HEp2 or HeLa cell. The only E. coli that showed LA pattern in both HEp-2 and HeLa cell assay was found negative by EPEC antisera. Similar predominance of DA pattern of adherence $(38.2 \%)$ of isolated $E$. coli has been reported in diarrhea cases from France. ${ }^{2}$ This finding indicated that EPEC strains that exhibited DA pattern on Hep-2 or HeLa cells should be considered as a potential pathogen. Recently, diarrheogenic E.coli has been defined as typical and atypical EPEC. ${ }^{12}$ Atypical EPEC exhibits DA and AA pattern while typical EPEC shows only LA pattern. ${ }^{13}$ So it appears that almost our entire adherence positive E. coli belonged to atypical EPEC group. However, in Chile and Brazil, LA pattern was found significantly more often in diarrhea cases. ${ }^{14,15}$ It appears that there are geographical variations in the distribution of diarrheogenic E. coli strains.
About 44\% serotype negative $E$. coli showed positive adherence on HEp-2 and HeLa cell assays. The cases that were positive by cell adhesion assays but negative by serotyping had watery diarrhea. This finding indicated that serotyping was not sensitive enough to detect all potential EPEC strains. Therefore, cell adhesion assay could be a more sensitive test for detection of EPEC. But, some isolates, which were positive by serotyping, did not show positive result by cell adhesion assays (Table 3 ). This discrepancy could not be well understood. It was possible that those serotype positive EPEC had other pathogenic mechanisms for inducing diarrhea.

The present study has indicated that diarrheogenic $E$. coli is an important cause of childhood diarrhea in northeastern peninsular Malaysia. Majority of isolated EPEC belonged to atypical group as determined by cell adhesion assays. Though, detection of EPEC by serotyping using specific antisera is convenient and quick, cell adhesion assay could be more sensitive than serotyping for detection of diarrheogenic $E$. coli.

\section{References}

1. Levine MM. Escherichia coli that cause diarrhea: enterotoxigenic, enteroinvasive, enterohaemorrhagic, and enteroadherent. J Infect Dis 1987; 155: 377-389.

2. Jallat C, Livrelli V, Michaud DA, Rich C, Joly E. Escherichia coli strain involved in diarrhea in France: High prevalence and heterogenicity of diffusely adhering strains. J Clin Microbiol 1993; 31: 20312037.

3. NM Thielman: Enteric Escherichia coli infections. Current Opinion in Infectious Disease 1994; 7 : 582-591.

4. Moyenuddin M, Rahman KM. Enteropathogenic Escherichia coli diarrhoea in hospitalized children in Bangladesh. J Clin Microbiology 1985; 22: 838-840.

5. Echeverria PK, Serichantalerg O, Changchawalit S, Baudy B, Levine MM, Orskov F, Orskov I. Tissue culture adherent Escherichia coli in infantile diarrhea. J Infect Dis 1992; 165: 141-143.

6. Nataro JP, Kaper JB, Robins R, Browne RR, Prado V, Vial P, Levin MM. Patterns of adherence of diarrheogenic Escherichia coli to HEp-2 cells, Pediatr Infect Dis J 1987; 6: 829-831.

7. Nataro JP, Kaper JB. Diarrheogenic Escherichia coli. Clinical Microbiology Review 1998; 11: 142-201.

8. Shariff M, Maharaj KB, Knutton S, Das BK, Saini S, Kumar R. Evaluation of the fluorescence actin staining 
test for detection of enteropathogenic Escherichia coli. J Clin Microbiology 1993; 31: 386-389.

9. Vlademir V, Cantarelli A, Takahashi I, Yanagihara Y, Akeda K, Imura T, Kodama G, Kono Y, et al. Cortactin is necessary for f-actin accumulation in pedestal structures induced by enteropathogenic Escherichia coli infection. Infection and Immunity 2002; 70: 2206-2209.

10. Kirubakaran C, Davidson GP, Hansman DH, Mckay G, Moore B, Lee P. Campylobacter as a cause of acute eneteritis in children in South Australia I: A 12 months study with controls. Med J Australia 1981; 2: 333-335.

11. Edward PR, Ewings WH. Identification of enterobacteriacae, $3^{\text {rd }}$ edition. Minneapolis, Burgess Publishing Co. 1972.
12. Levine MM, Prado V, Browne RR, Lior H, Kaper JB, Moseley SL, Gicouelais K, Nataro JP, Vial P, Tall B. Use of DNA probes and HEp-2 cell adherence assay to detect diarheagenic Escherichia coli. J Infect Dis 1988; 158: 224-228.

13. Kaper JB. Defining EPEC. Review of Microbiology 1996; 27:130-133.

14. Trabulsi LR, Keller R, Gomes TAT. Typical and atypical Enteropathogenic Escherichia coli. Emerging Infectious Diseases 2002; 8: 508-513.

15. Gomes TAT, Blake PA, Trabulsi LR. Prevalence of Eschericia coli strains with localized, diffuse and aggregative adherence to HeLa cells in infants with diarrhea and matched controls. J Clin Microbiology 1989; 27: 266-269. 